\title{
A new glanapterygine catfish of the genus Listrura (Siluriformes: Trichomycteridae) from southeastern Brazil, corroborated by morphological and molecular data
}

\author{
Leandro Villa-Verde ${ }^{1}$, Henrique Lazzarotto ${ }^{2}$ and Sergio M. Q. Lima ${ }^{3,4}$
}

Listrura costai, new species, is described from small streams in a swampy coastal plain in the rio Jurumirim basin, Angra dos Reis Municipality, Rio de Janeiro State, southeastern Brazil. The new species is morphologically very similar to L. nematopteryx and L. picinguabae, all possessing only one long pectoral-fin ray. It differs from its congeners by possessing an autapomorphic character: first hypobranchial with an anterior process (vs. process absent). Other features such as coloration, numbers of opercular and interopercular odontodes, number of anal-fin rays, head length, and shape of some bone structures help to distinguish the new species from L. nematopteryx and L. picinguabae. Molecular analyses using partial sequences of the mitochondrial DNA genes cytochrome oxidase c subunit 1 and cytochrome b from the new species and morphologically similar species are provided. The results about both molecular markers corroborate the validity of the new species by significant genetic distance values between it and congeneric species, and by its phylogenetic position in the hypotheses performed by maximum-parsimony method.

Listrura costai, espécie nova, é descrita de exemplares obtidos em pequenos córregos restritos à bacia do rio Jurumirim, município de Angra dos Reis, estado do Rio de Janeiro, sudeste do Brasil. A espécie nova é morfologicamente muito similar a L. nematopteryx e L. picinguabae, todas possuindo um único e longo raio na nadadeira peitoral. Difere-se dos seus congêneres por possuir um caráter autapomórfico: primeiro hipobranquial com um processo anterior (vs. processo ausente). Outras características como coloração, número de odontóides operculares e interoperculares, número de raios na nadadeira anal, e forma de algumas estruturas ósseas ajudam a diferenciar a nova espécie de L. nematopteryx e L. picinguabae. Análises moleculares usando sequências parciais dos genes mitocondriais citocromo oxidase c subunidade 1 e citocromo b da nova espécie e espécies morfologicamente similares são apresentadas. Os resultados de ambos os marcadores moleculares corroboram a validade da espécie nova pelos valores significativos das distâncias genéticas entre esta e as espécies congenéricas, e por sua posição filogenética nas hipóteses feitas pelo o método de máxima parcimônia.

Key words: Atlantic rain forest, Genetic distance, Mitochondrial DNA, Taxonomy.

\section{Introduction}

Trichomycterids of the genus Listrura de Pinna is an assemblage of small and unusual catfishes, distributed in coastal plains of southern and southeastern Brazil, from Rio de Janeiro to Santa Catarina States (de Pinna, 1988; Nico \& de Pinna, 1996; Landim \& Costa, 2002; de Pinna \& Wosiacki,
2002; Villa-Verde \& Costa, 2006). Listrura was proposed by de Pinna (1988) to include L. camposi (Miranda-Ribeiro), previously assigned to the genus Eremophilus von Humboldt by Miranda-Ribeiro (1957), and its type species $L$. nematopteryx de Pinna, also described by de Pinna (1988). Listrura camposi was described from a stream of the rio Ribeira de Iguape basin, Juquiá Municipality, São Paulo State

\footnotetext{
${ }^{1}$ Museu Nacional/UFRJ, Setor de Ictiologia, Departamento de Vertebrados, Quinta da Boa Vista s/n, São Cristóvão, 20940-040 Rio de Janeiro, RJ, Brazil. elffobr@yahoo.com.br.

${ }^{2}$ Programa de Pós-Graduação em Ecologia da Universidade Federal do Rio de Janeiro, Laboratório de Ecologia de Peixes, Departamento de Ecologia, Instituto de Biologia, Cidade Universitária, CCS, Bloco A, Cx. Postal 68020, 21941-590 Rio de Janeiro, RJ, Brazil. kiko_lazzarotto@yahoo.com.br

${ }^{3}$ Universidade Federal do Rio de Janeiro, Laboratório de Biodiversidade Molecular, Departamento de Genética, Instituto de Biologia, Cidade Universitária, CCS, Bloco A, 21941-470 Rio de Janeiro, RJ, Brazil.

${ }^{4}$ Universidade Federal do Rio Grande do Norte, Departamento de Botânica, Ecologia e Zoologia, 59978-970, Natal, RN, Brazil. smaialima@gmail.com
} 
(Miranda-Ribeiro, 1957; de Pinna 1988), and Nico \& de Pinna (1996) reported another population from a small coastal stream in Florianópolis Municipality, Santa Catarina State. Listrura nematopteryx occurs in small affluents to the rio Estrela basin, which flows to baía de Guanabara, Magé Municipality, Rio de Janeiro State (de Pinna, 1988; Nico \& de Pinna, 1996). More recently, three other species were described: $L$. boticario de Pinna \& Wosiacki, from small streams of the rio Guaraqueçaba basin, Guaraqueçaba Municipality (de Pinna \& Wosiacki, 2002), and from small streams of the rio Cachoeira, Antonina Municipality (Villa-Verde et al., 2008), both in Paraná State; L. picinguabae Villa-Verde \& Costa, from small streams of the rio da Fazenda basin, Ubatuba Municipality, São Paulo State (Villa-Verde \& Costa, 2006); and L. tetraradiata Landim \& Costa, from streams of the rio Ibicuíba basin, Saquarema Municipality, Rio de Janeiro State (Landim \& Costa, 2002).

The recent discoveries of new populations of Listrura are possibly a consequence of more frequent sampling directed to the specialized habitat occupied by their species, characterized by leaf litter and soft mud bottom of small, shallow water bodies commonly associated with small mountain streams. Other fish species are uncommon in this kind of habitat (see Habitat notes in Landim \& Costa, 2002; Villa-Verde \& Costa, 2006), making difficult the discovery of new populations of Listrura in ordinary ichthyological surveys. Some populations of Listrura were discovered by herpetologists who frequently collect frogs and tadpoles in biotopes with similar environmental features (e.g., L. picinguabae, firstly collected by the herpetologists Richard Schasse and Sérgio Potsch Carvalho e Silva; see paratypes in Villa-Verde \& Costa, 2006).

Recent taxonomic studies have employed molecular analysis methods, commonly using the mitochondrial DNA gene cytochrome oxidase c subunit 1 , as a supplement to the morphological data in the recognition of new fish species (e.g., Victor, 2007; Benine et al., 2009; Melo et al., 2011). This practice is very useful for morphologically similar species, such as in the case of the species of Listrura.

In August 2005, five specimens of a new population of Listrura were collected in rio Jurumirim basin, Angra dos Reis Municipality, Rio de Janeiro State, in an expedition coordinated by the second author. Later, new samples were collected in the same locality, totalizing 22 specimens examined herein. Morphological and molecular data revealed that the specimens from rio Jurumirim basin constitute a distinct taxon, which is herein formally described as a new species.

\section{Material and Methods}

Measurements and counts follow Costa (1992), with modifications according to Villa-Verde \& Costa (2006). Measurements are presented as percentages of standard length, except for subunits of head, which are presented as percentages of head length. Counts of number of dorsal and anal-fin rays include all rays (principal and predorsal/preanal, respectively). Osteological observations and counts were made only on cleared and stained (“CS”) specimens prepared according to Taylor \& van Dyke (1985). Osteological terminology follows Bockmann et al. (2004). Laterosensory system terminology follows Arratia \& Huaquín (1995).

Fragments of the mitochondrial DNA cytochrome b (Cytb) and cytochrome oxidase c subunit I (COI) genes from $L$. nematopteryx (one specimen), L. picinguabae (three), the new species (four), L. tetraradiata (five) and Listrura sp. from rio São João basin, Rio de Janeiro State (four) were sequenced. Total DNA was extracted from muscle tissue using the phenol/chloroform method described by Sambrook et al. (1989). The extracted DNA was precipitated with sodium acetate and ethanol, re-suspended in $50 \mu \mathrm{L}$ of ultrapure water, and stored at $-20^{\circ} \mathrm{C}$.

Partial sequences of Cytb gene were amplified using primers Cytb Siluri F (5'- CCA CCG TTG TAA TTC AAC TA 3') and Cytb Siluri R (5'- GAT TAC AAG ACC GGC GCT TT 3 '), both designed by the last author. For COI gene primers L5698-ASN (5' - AGG CCT CGA TCC TAC AAA GKT TTA GTT AAC -3'; Inoue et al., 2001) and H7271-COI (5'- GTG GTG GGC TCA TAC AAT AAA -3'; C. Oliveira, pers. comm.) were used. The polymerase chain reaction (PCR) amplification and sequencing for Cytb were as follows: one initial cycle of $4 \mathrm{~min}$ at $94^{\circ} \mathrm{C}$, followed by 35 cycles of $1 \mathrm{~min}$ at $94^{\circ} \mathrm{C}, 1 \mathrm{~min}$ at $62^{\circ} \mathrm{C}$, and $1 \mathrm{~min}$ at $72^{\circ} \mathrm{C}$, and a final extension at $72^{\circ} \mathrm{C}$ for $5 \mathrm{~min}$. The same conditions were used for COI, except for the use of $46^{\circ} \mathrm{C}$ as annealing temperature. The PCR products were purified and both strands were sequenced in an ABI 3730XL automatic sequencer.

Sequences were edited using the Seqman II (DNAStar, Inc., http://www.dnastar.com) and aligned in ClustalW software (Thompson et al., 1994). Levels of gene divergence between the sequences (Kimura 2-parameter model; Kimura, 1980) and phylogenetic analyses based on maximum-parsimony (MP) method (Swofford \& Berlocher, 1987) were performed in the MEGA5 software (Tamura et al., 2011), and made for Cytb and COI genes separately. The most parsimonious trees were obtained by max-mini branch-\&-bound algorithm (Purdom et al., 2000). The resultant topologies were statistically tested by the bootstrap method (Felsenstein, 1985) with 1,000 pseudoreplicates. The rooting was always taken on segment of $L$. tetraradiata, based on current hypothesis that it is a basal taxon of Listrura (Landim \& Costa, 2002).

The vouchers of the new species used in molecular analyses are deposited at MNRJ 39620, Listrura sp. at MNRJ 32026, L. nematopteryx at MNRJ 37022, L. picinguabae at LBP 3864, and L. tetraradiata at MNRJ 39068. The tissue samples of all material are deposited in LBDM 540 to LBDM 556. All mitochondrial DNA sequences obtained in present work were deposited in GenBank (accession codes HM245412 to HM245425, JN830893 to JN830897 and JQ231079 to JQ231088 - www.ncbi.nlm.nih.gov/GenBank).

Abbreviations for institutions are: LBDM, Laboratório de Biodiversidade Molecular, Universidade Federal do Rio de Janeiro, Rio de Janeiro, Brazil; LBP, Laboratório de Biologia e Genética de Peixes, Universidade Estadual Paulista - Botucatu, 
São Paulo, Brazil; MCP, Museu de Ciências e Tecnologia da Pontifícia Universidade Católica do Rio Grande do Sul, Porto Alegre, Brazil; MHNCI, Museu de História Natural Capão da Imbuia, Paraná, Brazil; MNRJ, Museu Nacional do Rio de Janeiro, Rio de Janeiro, Brazil; MZUSP, Museu Nacional da Universidade de São Paulo, São Paulo, Brazil; UFRJ, Laboratório de Sistemática e Evolução de Peixes Teleósteos, Universidade Federal do Rio de Janeiro, Rio de Janeiro, Brazil.

\section{Listrura costai, new species Figs. 1 and 2}

Holotype. MNRJ 31917, 31.3 mm SL, Brazil, Rio de Janeiro State, Angra dos Reis Municipality, small unnamed stream close to the road RJ-155 (Angra-Lídice), rio Jurumirim basin, 2255'24.7”S 044¹8’51.4”W, 11 Mar 2006, B. B. Costa, C. P. Bove, J. P. Moreira, \& W. J. E. M. Costa.

Paratypes. MNRJ 31535, 3, 25.9-32.1 mm SL, 2 CS, 20.4-26.5 mm SL, 22 Aug 2005, D. Eberienos, H. Lazzarotto, I. Montenegro \& J. Prata. MNRJ 31918, 5, 14.9-29.0 mm SL, 02 Jan 2008, H. Lazzarotto, J. Prata, L. Villa-Verde \& S. M. Q. Lima. MNRJ 39620, 4, 15.0-30.0 mm SL, 27 Jun 2008, D. Almeida, J. Prata \& S. M. Q. Lima. UFRJ 7214, 3, 28.1-33.5 mm SL, UFRJ 7215, 4, 26.0-32.0 mm SL, UFRJ 6577, 3 CS, 32.0-34.3 mm SL, 01 Oct 2005, H. Lazzarotto, M. Rheingantz \& R. Curcio. All from Brazil, Rio de Janeiro State, Angra dos Reis Municipality, swamp area close to the road RJ-155 (Angra-Lídice), about $1 \mathrm{~km}$ from road BR-101, rio Jurumirim basin, 22 ${ }^{\circ} 55^{\prime} 24.7$ ”S $044^{\circ} 18$ '37.5”W.

Diagnosis. Listrura costai is autapomorphically distinct from its congeners by possessing a small anterior process on the first hypobranchial (vs. process absent; Fig. 3). The new species is also distinguished from its congeners, except $L$. nematopteryx and $L$. picinguabae, by possessing only one pectoral-fin ray (vs. two to four rays). It differs from $L$. nematopteryx and $L$. picinguabae by having an inferior row of dots extending only on posterior half of body (vs. over almost the entire body), and posterior tip of ceratobranchial 5 strongly concave (vs. slightly concave or straight; Fig. 3). It further differs from $L$. nematopteryx by possessing a discontinuous lateral midline row of spots (vs. continuous row), lateral processes of urohyal reaching the anterior region of posterior ceratohyal (Fig. 4) [vs. reaching the posterior region of posterior ceratohial; see fig. 4B in Villa-Verde \& Costa, 2006], more dorsal and anal-fin rays (8-9 vs. 7-8 and 8-9 vs. 6-8, respectively), and more opecular and interopercular odontodes (6-8 vs. 4-6 and 8-12 vs. 5-7, respectively). It further differs from $L$. picinguabae by possessing a longer head (head length 11.7-15.3\% SL vs. 10.7$11.7 \%$ SL), more dorsal-fin rays (8-9 vs. 7), and anal-fin origin at vertical through region from centra of the $31^{\text {st }}$ to $34^{\text {th }}$ vertebrae (vs. $34^{\text {th }}$ to $36^{\text {th }}$ ).

Description. Morphometric data given in Table 1. Body elongate, subcylindrical at anterior portion of trunk, and strongly compressed at caudal peduncle. Dorsal and ventral profiles straight. Skin papillae minute.

Head depressed and trapezoidal. Snout blunt and slightly elongated. Mouth subterminal and narrow. Teeth conical, tips pointed and curved. Two rows of teeth in jaw. Premaxilla teeth 15-26; dentary teeth 13-21. Eyes anteriorly located on head, nearer to snout tip than to opercular patch of odontodes. Nasal, maxillary and rictal barbels well developed. Tip of nasal barbel reaching between posterior margin of interopercular patch of odontodes and posterior margin of opercular patch of odontodes. Tip of maxillary barbel reaching just posterior margin of opercular patch of odontodes. Tip of rictal barbel reaching between middle of interopercular patch of odontodes and posterior margin of opercular patch of odontodes. Anterior nostril opening anteriorly at base of nasal barbel. Posterior nostril located on anterior half of distance between anterior nostril and eye. Interopercular odontodes 8-12, opercular odontodes 6-8; odontodes conical, tips pointed and slightly curved.

Dorsal and anal fins approximately triangular. Dorsalfin origin on posterior half of trunk, at vertical between centra of $30^{\text {th }}$ and $35^{\text {th }}$ vertebrae. Anal-fin origin anterior to dorsal-fin origin (dorsal-fin origin on vertical through base of $3^{\text {rd }}$ anal-fin rays) to posterior to it, on vertical through base of $4^{\text {th }}$ dorsal-fin ray (Fig. 5), and between centra of $31^{\text {st }}$

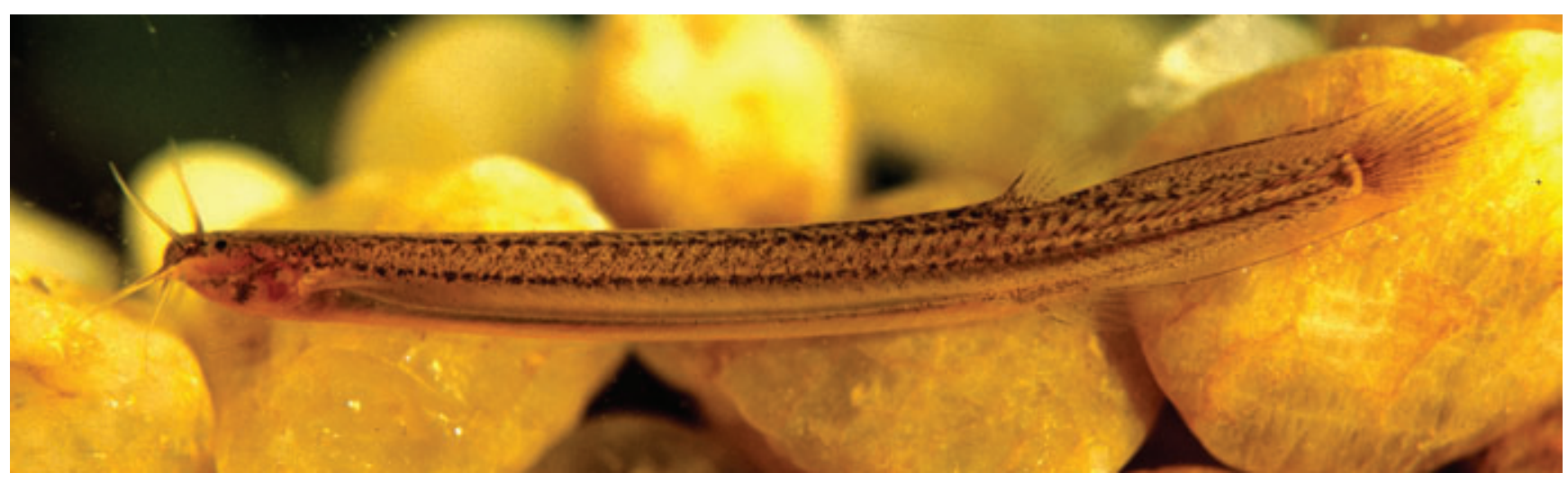

Fig. 1. Listrura costai, new species, holotype, MNRJ 31917, $31.3 \mathrm{~mm}$ SL, live specimen photograph; Brazil, Rio de Janeiro State, Angra dos Reis Municipality. Photo by Wilson J. E. M. Costa. 


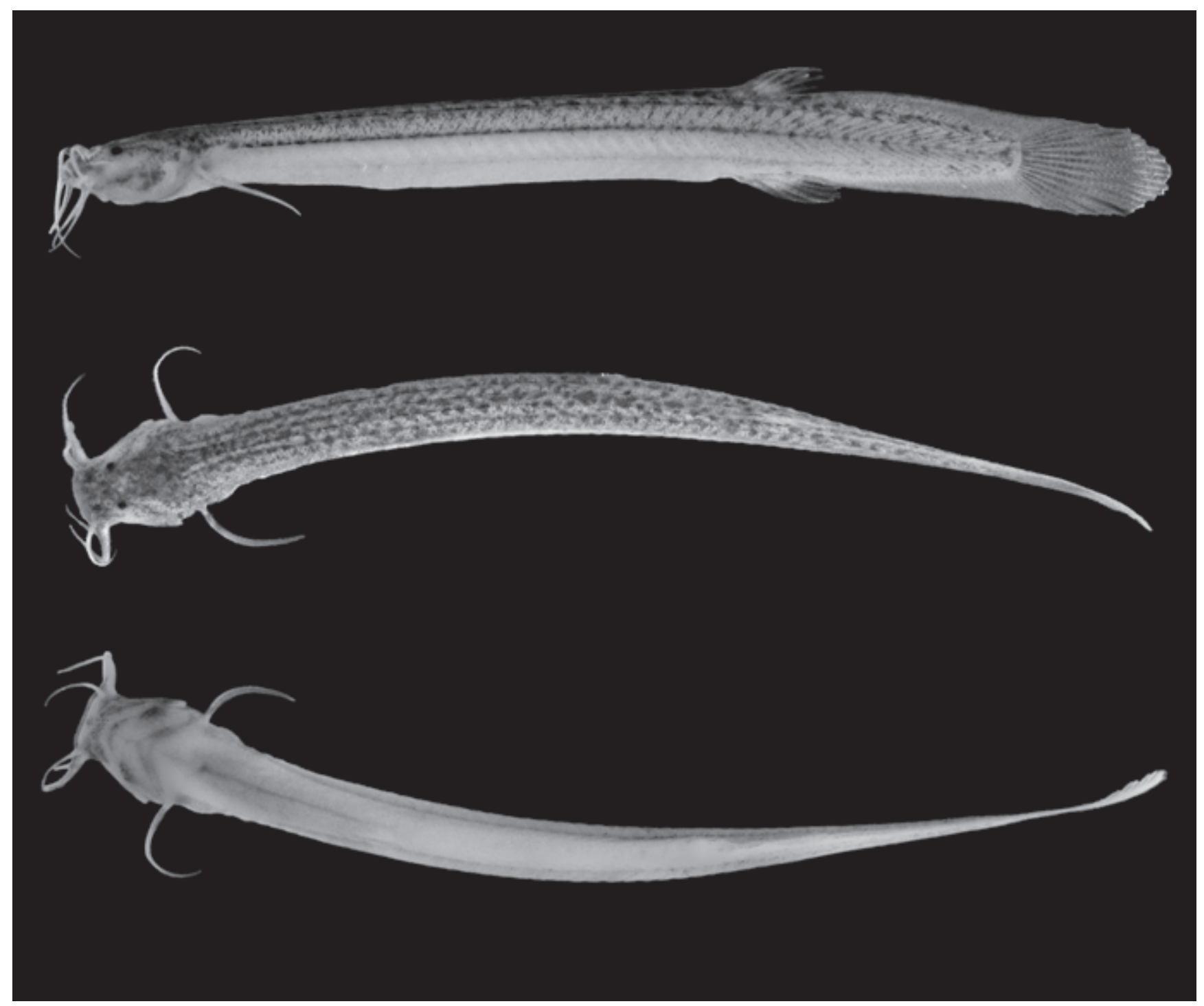

Fig. 2. Listrura costai, new species, holotype, MNRJ 31917, 31.3 mm SL; Brazil, Rio de Janeiro State, Angra dos Reis Municipality, in lateral (above), dorsal (middle), and ventral (below) views.

and $34^{\text {th }}$ vertebrae. Caudal fin elongate with posterior margin rounded, extending dorsally and ventrally to posterior margins of dorsal- and anal-fin bases, respectively. Pectoral fin with single filamentous ray. Pelvic fin and girdle absent. Dorsal-fin rays 8-9, all unbranched; anal-fin rays 8-9, all unbranched; principal caudal-fin rays 11 , dorsal-procurrent rays 28-35, ventral-procurrent rays 23-32. Pleural ribs 2-3. Total vertebrae 48-52. Branchial membranes attached only at anteriormost point of isthmus. Branchiostegal rays 6 .

Laterosensory system extremely reduced, without supraorbital, infraorbital, mandibular, preopercular, and otic canals (Fig. 6a). Postotic canal with two pores: anteriormost at vertical through anterior margin of opercular patch of odontodes; posteriormost at vertical just posterior to opercular patch of odontodes. Lateral line on trunk very short, with two pores: anteriormost largest, at vertical just posterior to pectoral-fin base; posteriormost below former in lateral view and just posterior to it.

Osteology. Anterior cornua of mesethmoid straight in dorsal view (Fig. 6a). Lateral ethmoid with lateral projection. Frontal and parieto-supraoccipital fully joined by sutures; cranial fontanel absent. Sphenotic, prootic and pterosphenoid entirely fused to each other. Vomer without posterior process. Parasphenoid without posterior process. Pterotic with lateral laminar expansion (Fig. 6a). Basioccipital and exoccipital fully fused to each other and posteriorly fused to Weberian capsule. Co-ossified basioccipital and exoccipital approximately triangular. Weberian capsule with small lateral opening on each side.

Autopalatine nearly square with curved lateral process (Fig. 


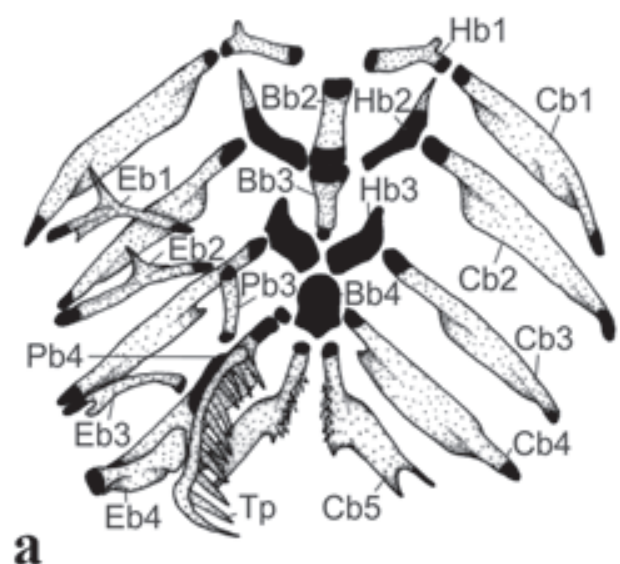

a

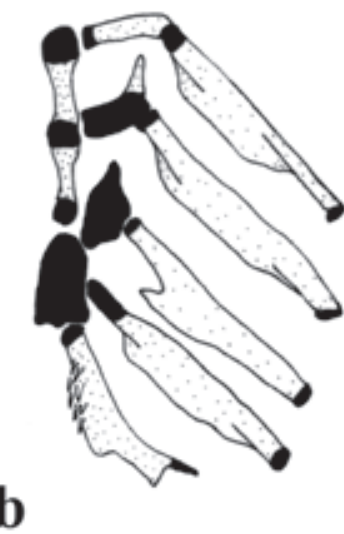

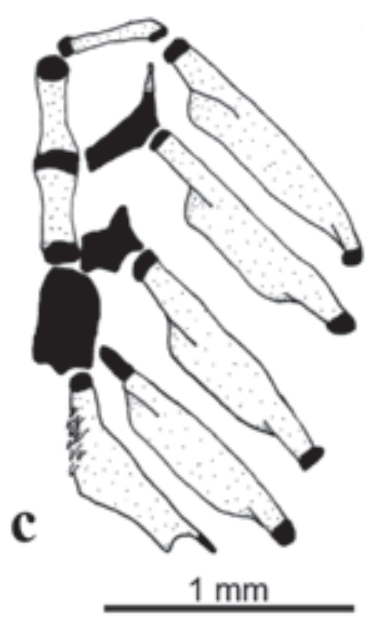

Fig. 3. Gill arches of (a) Listrura costai, new species, UFRJ 6577, paratype, $34.3 \mathrm{~mm}$ SL, (b) L. nematopteryx, UFRJ 5952, 29.4 mm SL, and (c) L. picinguabae, UFRJ 5951, paratype, $35.5 \mathrm{~mm} \mathrm{SL}$, dorsal view. Right dorsal elements of L. costai and left ventral and all dorsal elements of both L. nematopteryx and L. picinguabae not drawn. Bb2-4 - basibranchials 2 to 4; Cb1-5 - ceratobranchials 1 to 5; Eb1-4 - epibranchials 1 to 4; Hb1-4 - hypobranchials 1 to 4; Pb3-4 - pharyngobranchials 3 and 4; Tp - tooth plate.

6a). Premaxilla triangular. Maxilla elongate. Antorbital short and anteriorly expanded. Supraorbital extremely reduced.

Hyomandibula with elongated and narrow anterior process (Fig. 6b). Anterodorsal portion of quadrate laminar. Metapterygoid extremely reduced and articulating only with anterodorsal portion of quadrate through cartilaginous block. Preopercle straight. Odontodes disposed vertically on opercle and obliquely on interopercle.

Basibranchial 1 absent (Fig. 3a). Basibranchials 2 and 3 cylindrical, interconnected by cartilage. Cartilages on anteriormost border of basibranchial 2 and posteriormost border of basibranchial 3, respectively. One CS specimen (UFRJ 6577, $32.5 \mathrm{~mm}$ SL) with ossified basibranchial element peculiarly modified in crucifix shape (Fig. 6c; see Discussion). Basibranchial 4 flattened and fully cartilaginous. Hypobranchial 1 cylindrical and with anterior process (see Discussion). Hypobranchial 2 flattened and cartilaginous with anterolateral ossified process. Hypobranchial 3 flattened and fully cartilaginous. Hypobranchial 4 absent. Ceratobranchials 1, 2, 3, and 4 cylindrical, with slight posterior laminar process. Ceratobranchial 5 with strong concavity on posterior tip and dorsally-oriented conical teeth on anterior half. All ceratobranchials with cartilages on tips. Epibranchials 1, 2, and 3 thin; first with anterior and posterior processes, second with small anterior process, and third with small posterior uncinate process. Epibranchial 4 cylindrical with larger posterior laminar process. Epibranchial 5 absent or not evident. Pharyngobranchials 1 and 2 absent. Pharyngobranchial 3 cylindrical. Pharyngobranchial 4 fully cartilaginous and attached to tooth plate. Upper pharyngeal tooth plate with long ventromedially-oriented conical teeth.

Urohyal with narrow pointed and elongated lateral processes reaching to anterior region of posterior ceratohyal (Fig. 4). Two small condyles on anterior region of urohyal.
Deep depression on ventral hypohyal for articulation with urohyal condyle. Anterior ceratohyal cylindrical and constricted at midlengh. Posterior ceratohyal nearly triangular. Interceratohyal cartilage narrow.

Cleithrum flattened, slightly triangular and with large fenestra on central region (Fig. 6d). Scapulocoracoid narrow, fully cartilaginous and with narrow process on distal portion. Single proximal radial rounded and fully cartilaginous. Single pectoral-fin ray narrow and segmented.

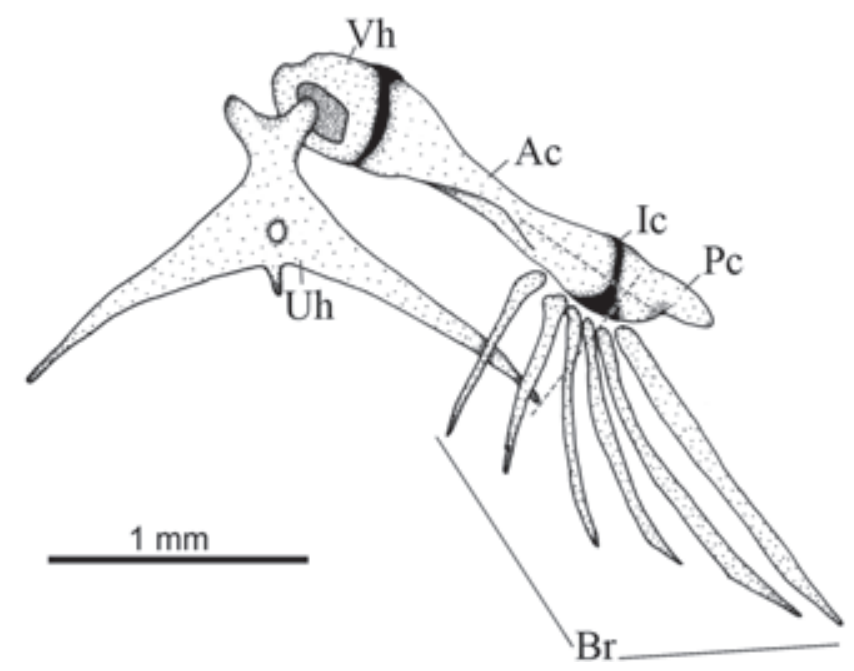

Fig. 4. Hyoid arch of Listrura costai, new species, UFRJ 6577, paratype, $34.3 \mathrm{~mm}$ SL, left side: ventral view. Dashed lines indicate the tip of the lateral process of urohyal in relation to ceratohyals. Ac - anterior ceratohyal; $\mathrm{Br}$ - branchiostegal rays; Ic - interceratohyal cartilage; Pc - posterior ceratohyal; Uh - urohyal; Vh - ventral hypohyal. 
Table 1. Morphometric data of holotype and 14 paratypes of Listrura costai, new species.

\begin{tabular}{lccc}
\hline & \multirow{2}{*}{ Holotype } & \multicolumn{2}{c}{ Paratypes } \\
\cline { 2 - 4 } & & Range & Mean \\
\hline Standard length (mm) & 31.3 & $20.4-34.3$ & 29.2 \\
Head length (mm) & 3.8 & $3.1-4.1$ & 3.7 \\
& Percentage of standard length & \\
Body depth & 9.7 & $7.8-10.3$ & 9.1 \\
Caudal peduncle depth & 6.3 & $5.0-8.4$ & 6.1 \\
Body width & 4.9 & $3.7-5.6$ & 4.4 \\
Caudal peduncle width & 1.9 & $1.7-2.6$ & 2.1 \\
Caudal peduncle length & 23.8 & $19.9-23.9$ & 22.2 \\
Dorsal-fin base length & 4.5 & $3.2-5.0$ & 4.2 \\
Anal-fin base length & 5.0 & $3.9-5.8$ & 5.2 \\
Pectoral-fin length & 13.2 & $10.8-15.2$ & 12.8 \\
Predorsal length & 69.6 & $69.4-77.8$ & 72.9 \\
Head length & 12.1 & $11.7-15.3$ & 12.7 \\
& & \\
Head depth & 56.9 & $48.9-65.1$ & 54.4 \\
Head width & 85.2 & $77.6-87.3$ & 83.1 \\
Interorbital width & 29.1 & $24.0-29.3$ & 27.3 \\
Preorbital length & 43.4 & $37.8-43.8$ & 40.1 \\
Eye diameter & 9.3 & $7.1-10.8$ & 9.4 \\
Mouth width & 48.9 & $44.4-55.1$ & 49.5 \\
Internarial width & 22.2 & $17.4-21.5$ & 19.9 \\
\hline
\end{tabular}

Caudal skeleton compact (Fig. 6e). Hypurals 1-2 and parhypural fused. Hypurals 1-2 almost completely fused to hypurals 3-5. Uroneural almost completely fused to caudal complex. Preural 1-ural 1 compound sometimes with accentuated dorsal concavity.

Coloration. Body light yellowish gray with minute dark brown to black dots on dorsal portion of flank and dorsum, more concentrated on lateral midline, and laterodorsal portion and dorsal midline of trunk to form three longitudinal rows of small, closely placed dark brown to black spots. Lateral midline spots to form discontinuous row; above lateral midline row of spots, dots often coalesced to form short, dark brown oblique lines near central portion of flank and oblique rows of small dark brown spots on side of caudal peduncle, all following myomeres; below lateral midline row of spots, minute brown dots to form narrow longitudinal row extending to posterior half of trunk. Few minute brown dots below lateral midline of caudal peduncle, usually arranged in oblique rows following
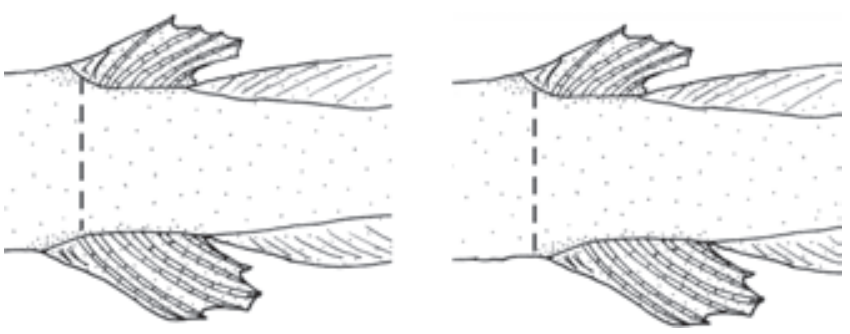

Fig. 5. Scheme of anal-fin origin in relation to dorsal-fin origin of Listrura costai, new species, showing the anteriormost (left) and posteriormost (right) positions of anal fin. myomeres. Venter yellowish white. Head pale brown on dorsal region, light yellowish gray on lateral and ventral regions; dark brown to black chromatophores concentrated over dorsal portion of head and snout, and interopercular and opercular regions, but absent or rare on infraorbital region, making distinctively unpigmented zone between snout, orbit and interopercle; small unpigmented zone on center of dorsal portion of head; dark chromatophores extending to ventral portion of head to produce dark transverse zone on chin and short dark zone on branchiostegal region. Barbels hyaline with brown base. Distal portion of dorsal and anal fins hyaline, proximal portion yellowish hyaline with dark brown chromatophores on fin rays. Narrow marginal black line on fin membrane adjacent to procurrent caudal-fin rays. Caudal fin yellowish hyaline with sparse dark brown chromatophores on fin rays. Pectoral fin hyaline.

Distribution. Listrura costai is known from two neighboring small unnamed coastal streams adjacent to the road RJ-155, Angra dos Reis Municipality, Rio de Janeiro State, Brazil, both draining into a swampy portion of the rio Jurumirim, close to its mouth (Fig. 7).

Habitat and ecological notes. Rio Jurumirim is the main canal of a small coastal basin of approximately $65 \mathrm{~km}^{2}$ which flows

Fig. 6. (next page) Skeleton of Listrura costai, new species, UFRJ 6577, paratype, $34.3 \mathrm{~mm}$ SL. (a) Skull and Weberian capsule in dorsal (left) and ventral (right) views. The arrow indicates the lateral laminar process of the pterotic. (b) Suspensorium and opercular apparatus, left side: lateral view. Dashed lines indicate the inclination of the opercular and interopercular paths of odontodes. (c) Basibranchial and hipobranchial elements of a CS specimen of L. costai, UFRJ 6577, paratype, $33.3 \mathrm{~mm} \mathrm{SL}$, dorsal view. (d) Pectoral girdle, left side: ventral view. (e) Caudal skeleton, left side: lateral view. An - antorbital; Au autopalatine; Ba+Ex - fused basioccipital-exoccipital; Be crucifix-shaped basibranchial element; Cb1-5 - ceratobranchials 1 to 5; Cl - cleithrum; Eb1-4 - epibranchials 1 to 4; Ep epioccipital; Fr - frontal; H3+H4+H5 - fused hypural 3-hypural 4-hypural 5; Hb1-4 - hypobranchials 1 to 4; Hs - hemal spine; Hy - hyomandibula; Io - interopercle; Le - lateral ethmoid; Llp12 - pores 1 to 2 of lateral line of trunk; Ma - maxilla; Me mesethmoid; Mt - metapterygoid; Ns - neural spine; Ob orbitosphenoid; Op - opercle; P1+U1 - fused preural 1-ural 1; $\mathrm{P} 2$ - preural centrum 2; $\mathrm{Pa}$ - parasphenoid; $\mathrm{Pb} 3-4$ pharyngobranchials 3 and 4; $\mathrm{Pf}$ - pectoral-fin ray; $\mathrm{Ph}+\mathrm{H} 1+\mathrm{H} 2$ fused parhypural -hypural 1-hypural 2; Pm - premaxilla; Po preopercle; Pop1-2 - pores 1 to 2 of postotic canal; Pp "posttemporosupracleithrum”; Pt - pterotic; Px - proximal radial; Qu - quadrate; Sc - scapulocoracoid; So - supraorbital; $\mathrm{Sp}+\mathrm{Pr}+\mathrm{Ps}$ - fused sphenotic-prootic-pterosphenoid; Su parieto-supraoccipital; Tp - tooth plate; Un - uroneural; Vo vomer; We - Weberian capsule. 

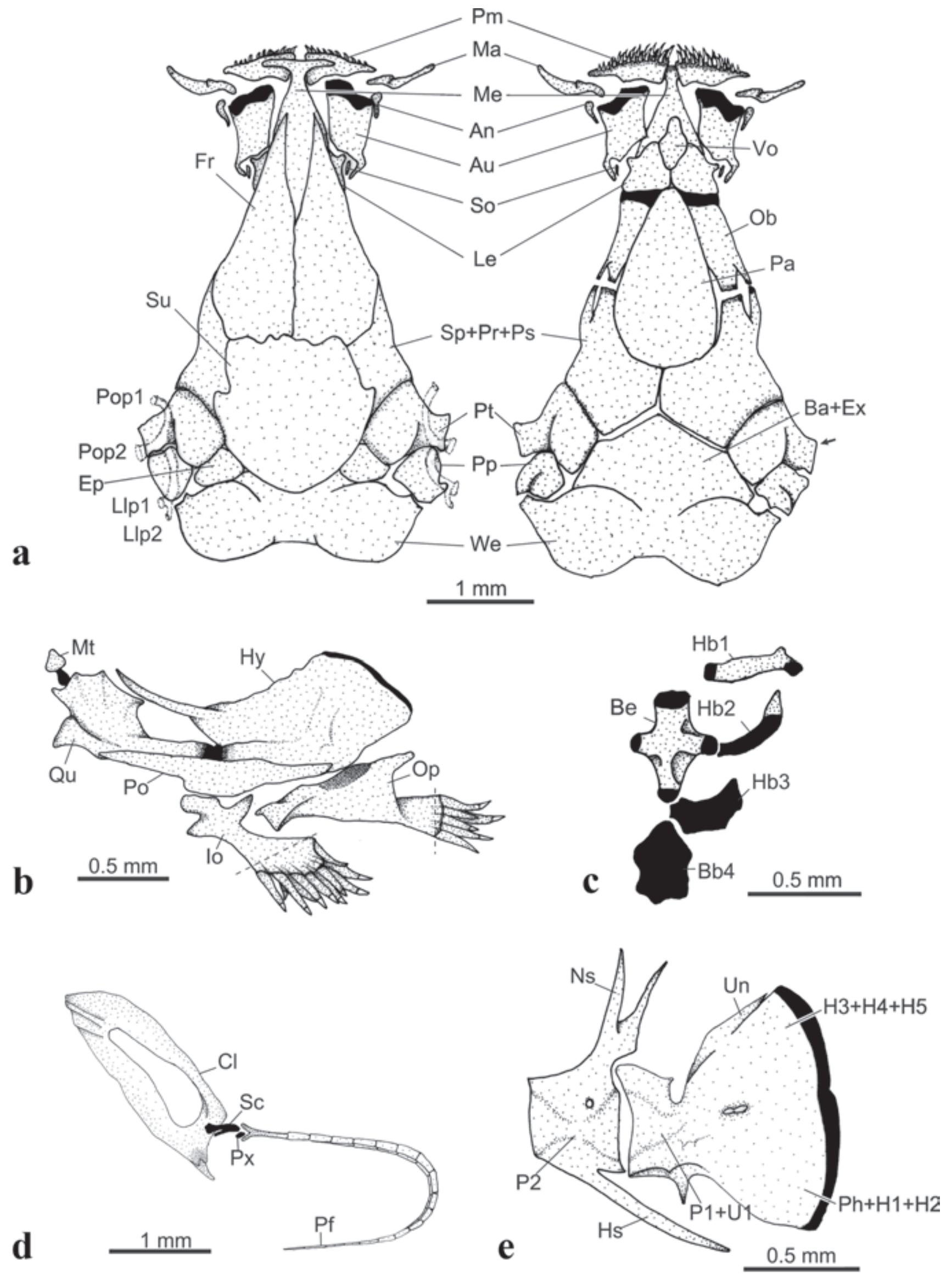
through well-preserved areas of Atlantic forest in the mountain range of the Serra da Bocaina. The rio Jurumirim forms a grassy lowland that becomes partially, and sometimes fully, flooded during periods of high rainfall. In this region, the grass vegetation has replaced the original Atlantic forest probably due to human action.

Most specimens of Listrura costai were collected in a narrow (about $1 \mathrm{~m}$ wide) and shallow (about $50 \mathrm{~cm}$ deep) clear water stream located in a swampy plain area densely vegetated with grass (Fig. 8). This site located in rio Jurumirim lowland, just upstream from a paved road (RJ-155), is right next to the pipe that runs underneath the road, draining the stream into a larger tributary of the main river. Most specimens were collected in a shallower portion of this stream (about $10 \mathrm{~cm}$ deep) either in the mud bottom or the thin layer of litter covering it (Fig. 8a). Some specimens were also collected at shallowest pools (less than $5 \mathrm{~cm}$ deep) adjacent to the stream (Fig. 8b). The locality where the holotype was found has similar characteristics. During the collection of the holotype, the water was clear with $\mathrm{pH} 6.1$ and temperature $25.5^{\circ} \mathrm{C}$ at 10:25 am.

Several specimens of $L$. costai were captured at night or dusk, suggesting a nocturnal habit. Furthermore, two collections during daylight resulted in no specimens captured, opposed to dusk/night time in the same day, when some individuals of $L$. costai were then found. The new species was found together with Hollandichthys multifasciatus (Eigenmann \& Norris), Gymnotus pantherinus Steindachner, Phalloceros sp., and Rivulus lazzarotoi Costa, the latter also endemic from rio Jurumirim basin (Costa, 2007). Other fishes, such as Astyanax taeniatus (Jenyns), Geophagus brasiliensis (Quoy \& Gaimard), Mimagoniates microlepis (Steindachner), Mugil sp., Rhamdia quelen (Quoy \& Gaimard), and Trichomycterus zonatus (Eigenmann), were also collected in the same stream, however just downstream from the road (Fig. 8c), an area with influence of marine tides, where L. costai was not caught.

Conservation remarks. The extremely restrict distribution, together with a high specificity of its natural habitat (swampy streams in lowland plain areas that rarely occur in southern Rio de Janeiro State watersheds) and relative proximity of human settlements make $L$. costai prone of becoming critically endangered or even extinct in a very short time period due to effects of human activities or stochastic events. However, no studies about population or geographical range reductions are available. Considering the IUCN categories and criteria to evaluate threatened species (IUCN, 2001, 2010), the actual information about $L$. costai allows only apply the criterion D2 (area of occupation less than $20 \mathrm{~km}^{2}$ ) for the category Vulnerable (VU). Conservation status of $L$. costai may be better circumscribed with a detailed analysis of its population density. Approval of conservation measures for this area is important not only to preserve this species but also for the conservation of other endemic species, such as Rivulus lazzarotoi.
Etymology. The species epithet is given for Dr. Wilson J. E. M. Costa, in recognition of his significant contributions to Neotropical Ichthyology, including the study with trichomycterid catfishes.

Molecular analyses. Partial sequences of the Cytb gene were taken from 17 specimens which resulted in a matrix with 1085 base pairs (bp) from which 949 sites were conserved, 136 were variable, and 123 parsimony informative. The nucleotide frequencies were $29.8 \%$ thymine, $29.6 \%$ cytosine, $26.2 \%$ adenine, and $14.4 \%$ guanine. In COI gene, partial sequences of only 12 specimens were amplified (amplification did not work in one specimen of $L$. costai, one of $L$. picinguabae, and three of Listrura sp.), resulting in a matrix with 789 bp from which 698 sites were conserved, 91 were variable, and 73 parsimony informative. The nucleotide frequencies were $30.0 \%$ thymine, $28.3 \%$ cytosine, $23.3 \%$ adenine, and $18.4 \%$ guanine. A single haplotype was found in both mitochondrial markers for each species with more than one sample, except for $L$. tetraradiata which presented two haplotypes. Values of molecular distances between $L$. costai, L. nematopteryx, L. picinguabae, Listrura sp., and $L$. tetraradiata are given in Table 2 . The intraspecific distance values for all species were zero in both mitochondrial genes, except in COI gene of L. tetraradiata that was $0.001 \pm$ 0.001 , due to a single nucleotide different on one specimen. Interspecific distance values for Cytb gene range from $0.036 \pm$ 0.006 between Listrura sp. and L. nematopteryx to $0.091 \pm 0.009$ between $L$. tetraradiata and L. nematopteryx. For COI gene,

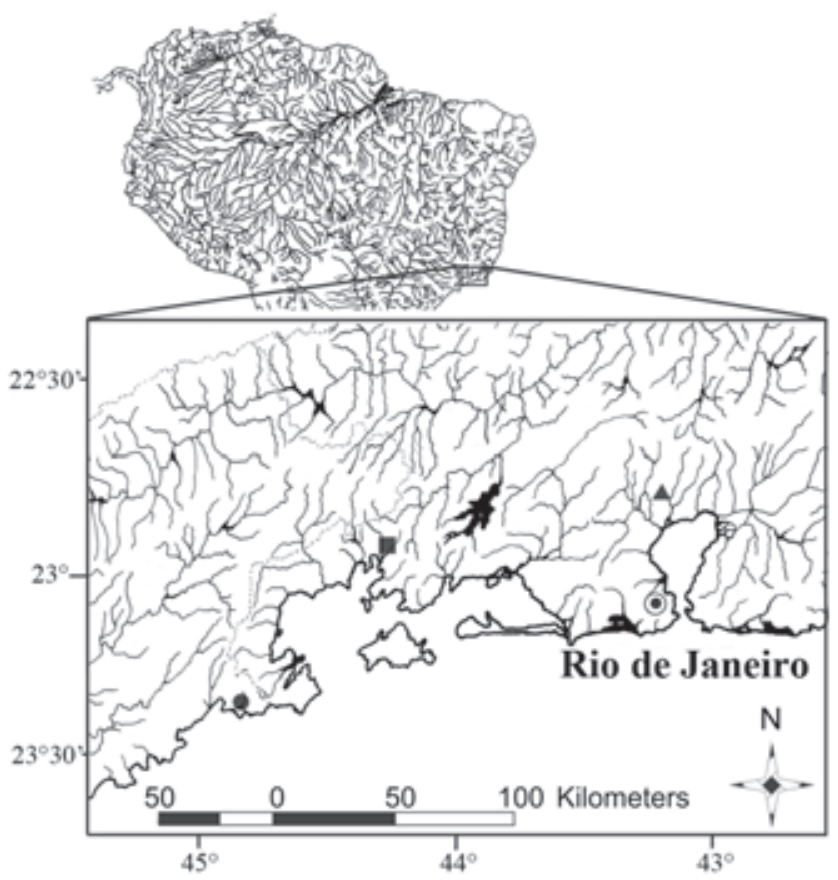

Fig. 7. Geographic distribution of Listrura costai, new species (square), and putatively more related valid species L. picinguabae (circle) and L. nematopteryx (triangle); southeastern Brazil. Dashed lines indicate the frontiers among São Paulo (west), Rio de Janeiro (east) and Minas Gerais (northwest) States. 


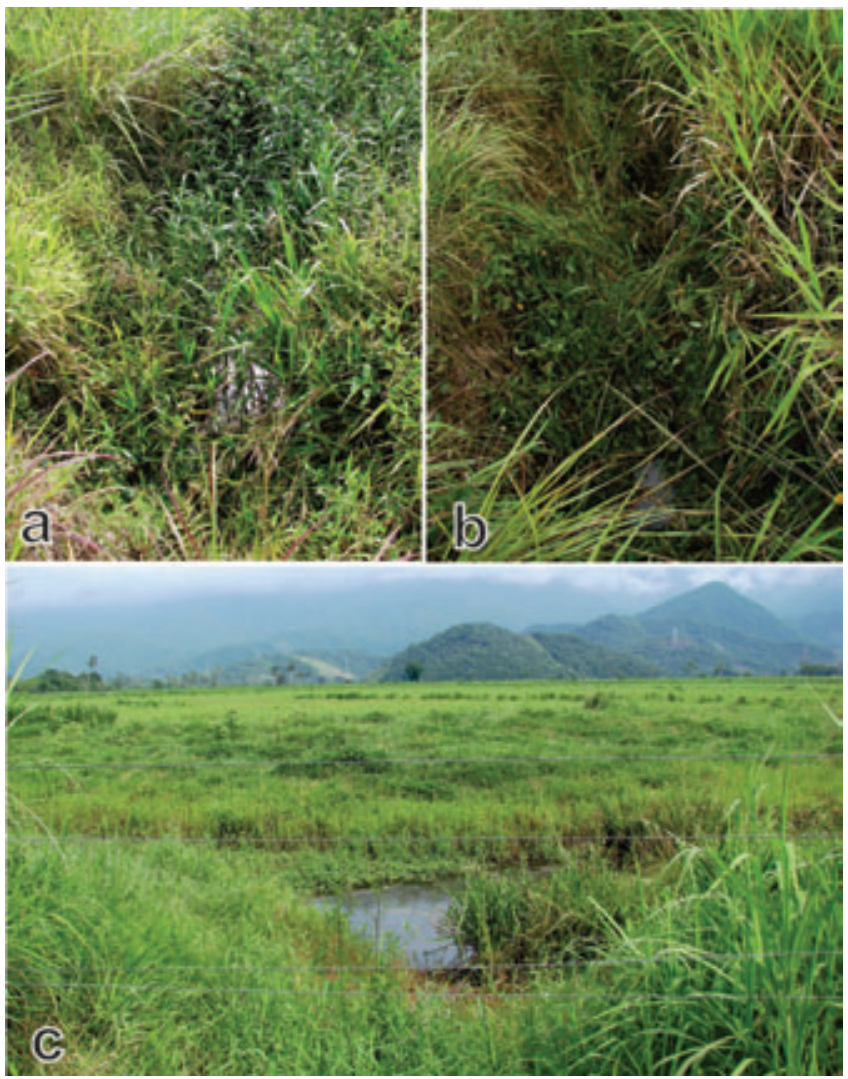

Fig. 8. Photographs of (a) small stream, (b) an adjacent pool, type locality of Listrura costai, new species; Brazil, Rio de Janeiro State, Angra dos Reis Municipality, swamp area close to the road RJ-155 (Angra-Lídice), about $1 \mathrm{~km}$ from road BR-

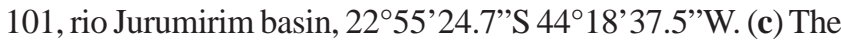
same stream just across the road where $L$. costai was not caught. Photos by Henrique Lazzarotto. the range was from $0.038 \pm 0.007$ between Listrura sp. and $L$. nematopteryx to $0.076 \pm 0.011$ between Listrura sp. and $L$. tetraradiata. Phylogenetic analyses for Cytb gene obtained 70875 most parsimonious trees, with length of 165 steps, consistency index 0.855263 and retention index 0.957115 . For COI gene, 315 most parsimonious trees were obtained, with length of 108 steps, consistency index 0.844444 and retention index 0.936364. Figure 9 presents two consensus trees obtained from most parsimonious Cytb- and COI-gene trees, respectively, with the bootstrap values for 1,000 pseudoreplicates. Both consensus topologies present a same monophyletic clade $(L$. nematopteryx plus Listrura sp.) well-supported by bootstrap values equal than $100 \%$. Listrura costai also shows wellsupported by $100 \%$ bootstrap in both topologies.

\section{Discussion}

de Pinna (1988) suggested the absence of the posterior process of vomer as a putative synapomorphy for the genus, corroborated by Landim \& Costa (2002) and VillaVerde \& Costa (2006). This feature was herein found in Listrura costai (Fig. 6a), as well as in all specimens of Listrura examined, reinforcing the synapomorphic condition of this character.

Listrura costai, L. nematopteryx, and L. picinguabae are morphologically very similar to each other when compared with the remaining congeners. They are the only valid species of the genus that present a single pectoralfin ray. The glanapterygines Pygidianops cuao Schaefer, Provenzano, de Pinna \& Baskin and P. amphioxus de Pinna \& Kirovsky also present this feature, but in the former it is unsegmented and shorter ( 0.3 times head length), with the fin expanded at the base (Schaefer et al., 2005). de Pinna \& Kirovsky (2011) did not inform the length of pectoral-fin ray for $P$. amphioxus, but the figures presented indicate

Table 2. Pairwise mtDNA Kimura 2 Parameter genetic distance values (mean \pm standard error) for cytochrome b gene (above diagonal) and cytochrome oxidase c subunit 1 gene (below diagonal) between Listrura costai, L. nematopteryx, L. picinguabae, Listrura sp., and L. tetraradiata. Diagonal shows the intraspecific genetic distance values for Cytb (above) and COI (below). Alpha-numeric codes below species names are GenBank accession codes.

\begin{tabular}{|c|c|c|c|c|c|}
\hline Species & 1 & 2 & 3 & 4 & 5 \\
\hline $\begin{array}{l}\text { 1. L. costai (rio Jurumirim basin) } \\
\text { Cytb - HM245418 to HM245421 } \\
\text { COI - HM245412 to HM245414 }\end{array}$ & $\begin{array}{l}0.000 \pm 0.000 \\
0.000 \pm 0.000\end{array}$ & $0.048 \pm 0.007$ & $0.052 \pm 0.007$ & $0.045 \pm 0.007$ & $0.078 \pm 0.009$ \\
\hline $\begin{array}{l}\text { 2. L. nematopteryx (rio Estrela basin) } \\
\text { Cytb - HM245425 } \\
\text { COI - HM245417 }\end{array}$ & $0.039 \pm 0.007$ & $\begin{array}{l}0.000 \pm 0.000 \\
0.000 \pm 0.000\end{array}$ & $0.052 \pm 0.007$ & $0.036 \pm 0.006$ & $0.091 \pm 0.009$ \\
\hline $\begin{array}{l}\text { 3. L. picinguabae (rio da Fazenda basin) } \\
\text { Cytb - HM245422 to HM245424 } \\
\text { COI - HM245415 and HM245416 }\end{array}$ & $0.050 \pm 0.008$ & $0.048 \pm 0.008$ & $\begin{array}{l}0.000 \pm 0.000 \\
0.000 \pm 0.000\end{array}$ & $0.051 \pm 0.007$ & $0.089 \pm 0.009$ \\
\hline $\begin{array}{l}\text { 4. Listrura sp. (rio São João basin) } \\
\text { Cytb - JN830893 to JN830896 } \\
\text { COI - JN830897 }\end{array}$ & $0.042 \pm 0.007$ & $0.038 \pm 0.007$ & $0.052 \pm 0.008$ & $\begin{array}{l}0.000 \pm 0.000 \\
0.000 \pm 0.000\end{array}$ & $0.079 \pm 0.009$ \\
\hline $\begin{array}{l}\text { 5. L. tetraradiata (rio Ibicuíba basin) } \\
\text { Cytb - JQ231084 to JQ231088 } \\
\text { COI - JQ231079 to JQ231083 }\end{array}$ & $0.070 \pm 0.010$ & $0.070 \pm 0.010$ & $0.069 \pm 0.010$ & $0.076 \pm 0.011$ & $\begin{array}{l}0.000 \pm 0.000 \\
0.001 \pm 0.001\end{array}$ \\
\hline
\end{tabular}


that it is less than 0.4 times head length. In opposition, those species of Listrura present a segmented and longer (0.7-1.1 times head length) pectoral-fin ray, with the fin narrow at the base. The presence of a single pectoral-fin ray in both taxa is clearly a convergence.

The molecular analyses present interesting results about the relationships among the species used in this study. The population of Listrura from rio São João basin (herein treated as Listrura sp.) is clearly a distinct taxon by absence of the dorsal fin. It also displays only one pectoral-fin ray. However, the overall results of the molecular analyses indicate a close relationship between Listrura sp. and L. nematopteryx. The lowest values observed in genetic distance were between these two species for both Cytb and COI genes, $0.036 \pm 0.006$ and $0.038 \pm 0.007$ respectively (Table 2 ). On other hand, the observed values between $L$. costai and the remaining species were higher, range from $0.045 \pm 0.007$ to $0.078 \pm$ 0.009 for Cytb gene and from $0.039 \pm 0.007$ to $0.070 \pm 0.010$ for COI gene. It means that the degree of genetic divergence of $L$. costai is consistent with those observed in its congeners (see the interspecific values for remaining species analyzed; Table 2). The phylogenetic analyses of both genes indicate that $L$. costai comprises a well-defined distinct monophyletic taxon with $100 \%$ bootstrap value (Fig. 9). In fact, it has been observed in a more inclusive phylogenetic analysis for Listrura using morphological data (Villa-Verde, 2006). Phylogenetic analyses of the genus using both morphological and molecular data are being made (by senior author) and the conclusive results also corroborate the species status of Listrura costai.

An anterior process on the first hypobranchial was observed in all CS specimens examined (5) of L. costai, although there is a variation in the degree of development (Figs. 3a, 6c). The presence of this process contrasts with its absence in all other species of the genus (see Comparative Material Examined for a relation of total number of CS specimens examined), therefore this character can be considered as an autapomorphy for the new species. A similar process was also reported and considered as a putative synapomorphy for basal trichomycterid subfamilies Trichogeninae and Copionodontinae (de Pinna, 1998). On the basis of the current hypotheses of phylogenetic relationship among the subfamilies of Trichomycteridae (de Pinna, 1998: fig. 10), the process is herein considered as homoplastic character for basal trichomycterids and $L$. costai.

The crucifix-shaped basibranchial element observed in one CS specimen of $L$. costai (Fig. 6c) is very similar to that described and used as diagnostic character for Stauroglanis gouldingi de Pinna, also observed from a single CS specimen (MZUSP 30411, paratype; de Pinna, 1989). The genus Cruciglanis Ortega-Lara \& Lehmann (Pseudopimelodidae) also displays a crucifix-shaped basibranchial element, but it is relatively different from Stauroglanis as discussed by Ortega-Lara \& Lehmann (2006). Another pseudopimelodid, Microglanis pataxo Martins-Pinheiro, Aranda \& Chamon, shows a crucifixshaped basibranchial element, however it is fully

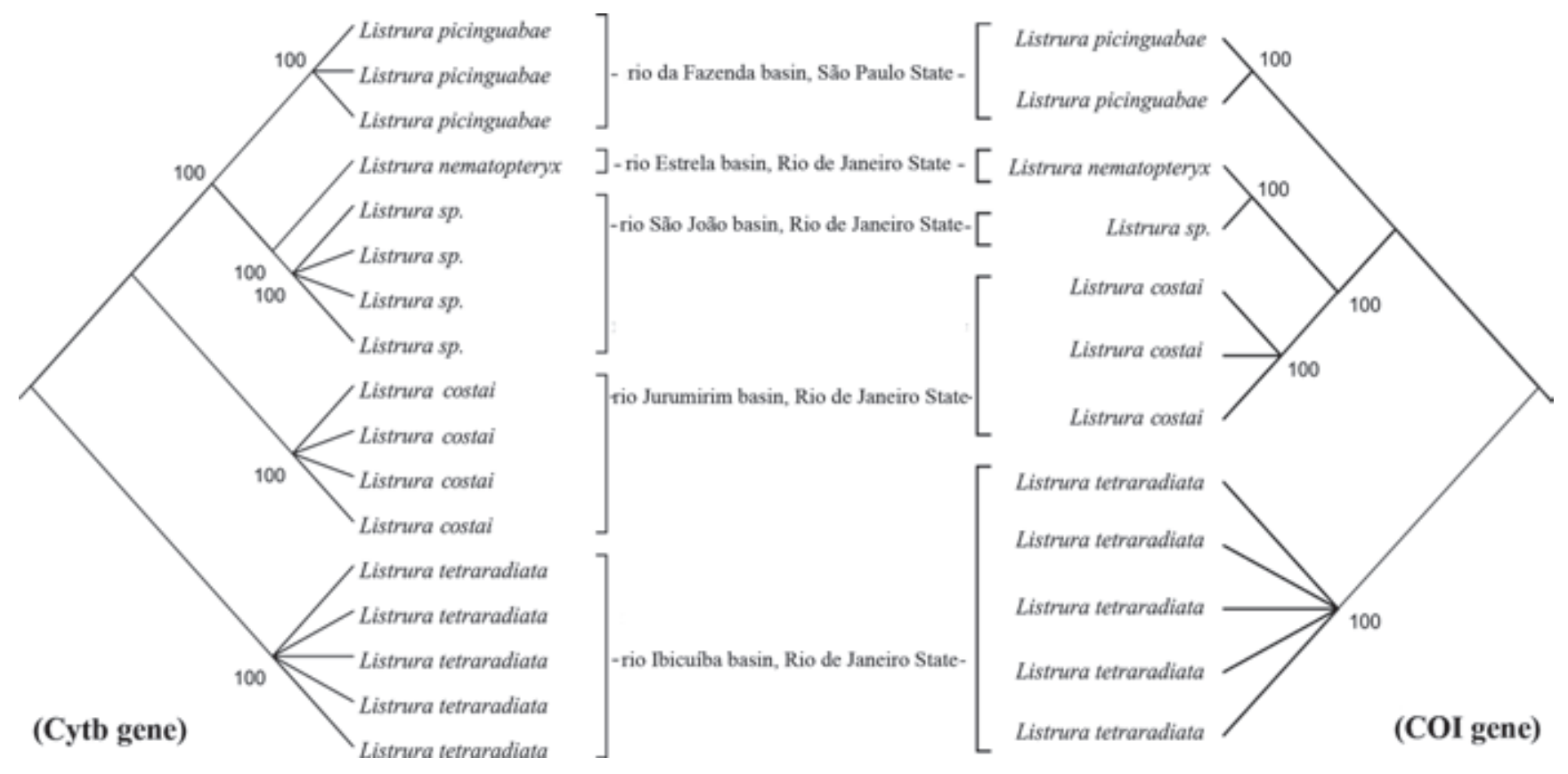

Fig. 9. Two Maximum Parsimony consensus trees for the mitochondrial DNA genes Cytochrome b (left) and Cytochrome Oxidase C subunit I (right), respectively. Numbers indicate the bootstrap values with 1,000 pseudoreplicates. Segments with values $\leq 50 \%$ were condensed and values not shown. 
cartilaginous (Sarmento-Soares et al., 2006: fig. 7). In fact, all other S. gouldingi examined later presented typical basibranchials 2 and 3 (M. C. C. Pinna, pers. comm.), demonstrating that the crucifix-shaped basibranchial element observed in L. costai and S. gouldingi is an anomaly.

The occurrence area of $L$. costai is geographically situated between the distributional range of $L$. nematopteryx and $L$. picinguabae, about $120 \mathrm{~km}$ and $70 \mathrm{~km}$ of distance, respectively (Fig. 7). The new species occurs in the lowland of a small coastal river basin, draining a restricted area between the Serra da Bocaina slopes and the sea, and isolated from adjacent coastal basins by smaller mountains. Thus, L. costai is not likely to be found elsewhere out of this area.

Comparative material examined. Copionodon orthiocarinathus, MNRJ 21268, 260 (17 CS), 28.1-69.4 mm SL, Brazil, Bahia State, Mucugê, rio Piabas, $12^{\circ} 57^{\prime} 0^{\prime \prime} \mathrm{S} 041^{\circ} 16^{\prime} 39^{\prime}$ 'W. Glanapteryx anguilla, MZUSP 36530, 19 (2 CS), 33.7-63.2 mm SL, Brazil, Amazonas State, rio Negro, igarapé São João, near Tapurucuara, $00^{\circ} 24^{\prime}$ S 0650'' W. Listrura boticario, MHNCI 11689, 6 (1 CS), 26.1-34.3 mm SL, Brazil, Paraná State, Antonina Municipality, small stream tributary to rio Copiuva, rio Cachoeira basin, $25^{\circ} 19^{\prime} 25.1^{\prime \prime} \mathrm{S}$ 048 40’31.0”W; MNRJ 32444, 21 (2 CS), 16.2-40.2 mm SL, from same locality; MHNCI 11690, 2 (1 CS), 38.0-40.5 mm SL, small abandoned meander of an unnamed river, rio Cachoeira basin, 2522'45.22”S 4842’40.69”'W; MNRJ 32442, 1, 37.2 mm SL, Guaraqueçaba Municipality, rio da Figueira, rio Morato basin, 2510’43.6”' 048 $18^{\prime} 42.4^{\prime \prime}$ W; MZUSP 69573, holotype, $36.7 \mathrm{~mm}$ SL, from same locality. Listrura camposi, MZUSP 3426, holotype, 37.2 mm SL, Brazil, São Paulo State, Juquiá Municipality, ribeirão Poço Grande, rio Ribeira de Iguape basin $24^{\circ} 15^{\prime} \mathrm{S} 047^{\circ} 37^{\prime} \mathrm{W}$; MNRJ 37023, 4 (2 CS), 29.6-43.4 mm SL, Pedro de Toledo Municipality, stream tributary to rio Itariri, rio Ribeira de Iguape basin, $24^{\circ} 15^{\prime} 06^{\prime}$ 'S 047014'53”W; MNRJ 33031, 17 (1 CS), 17.3-51.0 mm SL; MZUSP 95189, 25 (2 CS), 20.7-46.4 mm SL, all from same locality; UFRJ 1278, 1, 39.5 mm SL, Santa Catarina State, Florianópolis Municipality, ribeirão da Ilha, $27^{\circ} 42^{\prime}$ 'S $048^{\circ} 32^{\prime}$ W; UFRJ 1279,1 CS, $35.1 \mathrm{~mm}$ SL, from same locality. Listrura nematopteryx, MNRJ 10970, 8 (1 CS) paratypes, 25.1-30.9 mm SL, Brazil, Rio de Janeiro State, Magé Municipality, marsh adjacent to rio Imbariê, rio Estrela

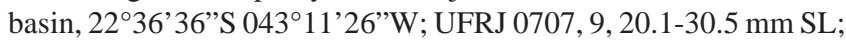
UFRJ 5952, 5 CS, 21.0-29.4 mm SL, both from same locality. Listrura picinguabae, MCP 38921, 2 paratypes, 31.8-42.5 mm SL. Brazil, São Paulo State, Ubatuba Municipality, small stream, rio da Fazenda basin, $23^{\circ} 20^{\prime}$ 'S $044^{\circ} 45^{\prime}$ W, UFRJ 6111, holotype, 48.6mm SL; UFRJ 5948, 1 paratype, 35.5 mm SL; UFRJ 5949, 2 paratypes, 24.3-32.3 mm SL; UFRJ 5950, 15 paratypes, 29.4-45.3 mm SL; UFRJ 5951, 4 CS paratypes, 31.3-35.5 mm SL; UFRJ 5991, 2 CS paratypes, 26.3-31.9 mm SL; UFRJ 6138, 5 CS paratypes, 36.0-50.2 mm SL, all from same locality. Listrura sp., MNRJ 32026, 46 (3 CS), 8.8-41.4 mm SL. Brazil, Rio de Janeiro State, Silva Jardim Municipality, rio das Panelas, rio São João basin, 2235'19”'S 042³6'12”W, MZUSP 93882, 21 (2 CS), 12.3-32.6 $\mathrm{mm}$ SL, from same locality. Listrura tetraradiata, MNRJ 31534, 17 (4 CS) paratypes, 15.5-39.9 mm SL. Brazil, Saquarema Municipality, rio da Represa, rio Ibicuíba basin, $22^{\circ} 56^{\prime} \mathrm{S} 042^{\circ} 31^{\prime} \mathrm{W}$, MNRJ 39068, 6, 29.2-36.7 mm SL; MZUSP 52572, holotype, $37.3 \mathrm{~mm}$ SL; UFRJ 4586, 17 paratypes, 10.8-43.1 mm SL; UFRJ 4588, 3 CS paratypes, 21.1-40.6 mm SL; UFRJ 4590, 7 paratypes, 24.5-44.4 mm SL, all from same locality. Trichogenes longipinnis,
MNRJ 13809, 132 (6 CS), 30.1-104.6 mm SL. Brazil, Rio de Janeiro State,Parati Municipality, stream tributary to rio Parati-

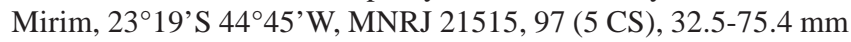
SL, from same locality.

\section{Acknowledgements}

Special thanks to Bruno Costa, Cláudia Bove, Daniel Eberienos, Iby Montenegro, Jade Prata, João P. Moreira, Marcelo Rheingantz, Rafael Curcio, and Wilson Costa for help in field works. We are also grateful to Wilson Costa for the loan of specimens from UFRJ, photograph of the holotype and significant contributions on the manuscript, to Osvaldo Oyakawa and Vinícius Abilhoa for the loan of specimens from MZUSP and MHNCI, respectively, to Marcelo R. Britto for the loan of specimens from MNRJ and pertinent suggestions on the manuscript, to Roberto E. Reis for providing the base map, to Mário C. C. de Pinna for information about Stauroglanis gouldingi, to Antonio Solé-Cava for logistic support and comments on the molecular analyses, and to Claudio Oliveira for donating the tissue samples of $L$. picinguabae and providing information about primer H7271COI. Field expeditions were partially funded by ACSI/NSF (All Catfish Species Inventory/National Science Foundation, NSF DEB-0315963). This work was also supported by CNPq (Conselho Nacional de Desenvolvimento Científico e Tecnológico, Ministério de Ciência e Tecnologia) and CAPES (Coordenação de Aperfeiçoamento de Pessoal de Nível Superior). The present work was performed on the scope of PROAMA-CpC (Programa de Avaliação de Mananciais, ONG Conhecer para Conservar). This study was originally developed as part of a work about systematics of the genus Listrura by the first author for obtaining the degree of Master of Science in Zoology at the Programa de Pós-Graduação em Zoologia (PPGZoo), Museu Nacional/UFRJ, Rio de Janeiro, Brazil.

\section{Literature Cited}

Arratia, G. \& L. Huaquín. 1995. Morphology of the lateral line system and of the skin of diplomystid and certain primitive loricarioid catfishes and systematic and ecological considerations. Bonner Zoologische Monographien, 36: 1-109.

Benine, R. C., T. C. Mariguela \& C. Oliveira. 2009. New species of Moenkhausia Eigenmann, 1903 (Characiformes: Characidae) with comments on the Moenkhausia oligolepis species complex. Neotropical Ichthyology, 7: 161-168.

Bockmann, F. A., L. Casatti \& M. C. C. de Pinna. 2004. A new species of trichomycterid catfish from the Rio Paranapanema basin, southeastern Brazil (Teleostei: Siluriformes), with comments on the phylogeny of the family. Ichthyological Exploration of Freshwaters, 15: 225-242.

Costa, W. J. E. M. 1992. Description de huit nouvelles espèces du genre Trichomycterus (Siluriformes: Trichomycteridae), du Brésil oriental. Revue Française d'Aquariologie et Herpétologie, 18: 101-110.

Costa, W. J. E. M. 2007. Rivulus lazzarotoi n. sp. (Teleostei: Cyprinodontiformes: Rivulidae), a new killifish from the 
Jurumirim River basin, southeastern Brazil. Aqua, Journal of Ichthyology and Aquatic Biology, 12: 123-128.

Felsenstein, J. 1985. Confidence limits on phylogenies: An approach using the bootstrap. Evolution, 39: 783-791.

Inoue, J. G., M. Miya, K. Tsukamoto \& M. Nishida. 2001. A mitogenomic perspective on the basal teleostean phylogeny: resolving higher-level relationships with longer DNA sequences, Molecular Phylogenetic Evolution, 20: 272-285.

IUCN - International Union for Conservation of Nature. 2001. IUCN Red List Categories and Criteria: Version 3.1. IUCN Species Survival Commission. IUCN, Gland, Switzerland and Cambridge, United Kingdom.

IUCN Standards and Petitions Subcommittee. 2010. Guidelines for Using the IUCN Red List Categories and Criteria, Version 8.1, Standards and Petitions Subcommittee, 85p. Available from: http://intranet.iucn.org/webfiles/doc/SSC/RedList/ RedListGuidelines.pdf (September 14, 2012).

Kimura, M. 1980. A simple method for estimating evolutionary rate of base substitutions through comparative studies of nucleotide sequences. Journal of Molecular Evolution, 15: 111-120.

Landim, M. I. \& W. J. E. M. Costa. 2002. Listrura tetraradiata (Siluriformes: Trichomycteridae): a new glanapterygine catfish from the southeastern Brazilian coastal plains. Copeia, 2002: 152-156.

Melo, B. F., R. C. Benine, T. C. Mariguela \& C. Oliveira. 2011. A new species of Tetragonopterus Cuvier, 1816 (Characiformes: Characidae: Tetragonopterinae) from the rio Jari, Amapá, northern Brazil. Neotropical Ichthyology, 9: 49-56.

Miranda-Ribeiro, P. 1957. Notas para estudo dos Pygidiidae brasileiros (Pisces - Pygidiidae). Papéis Avulsos do Departamento de Zoologia da Secretaria de Agricultura de São Paulo, 13: 71-73.

Nico, L. G. \& M. C. C. de Pinna. 1996. Confirmation of Glanapteryx anguilla (Siluriformes, Trichomycteridae) in the Orinoco River Basin, with notes on the distribution and habitats of the Glanapteryginae. Ichthyological Exploration of Freshwaters, 7: 27-32.

Ortega-Lara, A. \& P. Lehmann. 2006. Cruciglanis, a new genus of Pseudopimelodid catfish (Ostariophysi: Siluriformes) with description of a new species from the Colombian Pacific coast. Neotropical Ichthylogy, 4: 147-156.

de Pinna, M. C. C. 1988. A new genus of trichomycterid catfish (Siluroidei, Glanapteryginae), with comments on its phylogenetic relationships. Revue suisse de Zoologie, 95: 113-128.

de Pinna, M. C. C. 1989. A new sarcoglanidine catfish, phylogeny of its subfamily, and an appraisal of the phyletic status of the Trichomycterinae (Teleostei, Trichomycteridae). American Museum Novitates, 2950: 1-39.

de Pinna, M. C. C. 1998. Phylogenetic relationships of Neotropical Siluriformes (Teleostei: Ostariophysi): historical overview and synthesis of hypotheses. Pp. 289-330. In: Malabarba, L. R., R. E. Reis, R. P. Vari, Z. M. Lucena \& C. A. S. Lucena (Eds.). Phylogeny and Classification of Neotropical Fishes. EDIPUCRS, Porto Alegre, Brazil, 729p.

de Pinna, M. C. C. \& A. L. Kirovsky. 2011. A new species of sanddwelling catfish, with a phylogenetic diagnosis of Pygidianops Myers (Siluriformes: Trichomycteridae: Glanapteryginae). Neotropical Ichthyology, 9: 493-504. de Pinna, M. C. C. \& W. B. Wosiacki. 2002. A new interstitial catfish of the genus Listrura from Southern Brazil (Siluriformes: Trichomycteridae: Glanapteryginae). Proceedings of the Biological Society of Washington, 115: 720-726.

Purdom, P. W., P. G. Bradford, K. Tamura \& S. Kumar 2000. Single column discrepancy and dynamic max-mini optimizations for quickly finding the most parsimonious evolutionary trees. Bioinformatics, 16: 140-151.

Sambrook, J., E. F. Fritsch \& T. Maniatis. 1989. Molecular cloning - a laboratory manual. Cold Spring Harbor Laboratory Press, Cold Spring Harbor, EUA.

Sarmento-Soares, L. M., R. F. Martins-Pinheiro, A. T. Aranda \& C. Chamon. 2006. Microglanis pataxo, a new catfish from southern Bahia coastal rivers, northeastern Brazil (Siluriformes: Pseudopimelodidae). Neotropical Ichthyology, 4: 157-166.

Schaefer, S. A., F. Provenzano, M. de Pinna \& J. N. Baskin. 2005. New and noteworthy Venezuelan glanapterygine catfishes (Siluriformes, Trichomycteridae), with discussion of their biogeography and psammophily. American Museum Novitates, 3496: 1-27.

Swofford, D. L. \& S. H. Berlocher. 1987. Inferring evolutionary trees from gene frequency data under the principle of maximum parsimony. Systematic Zoology, 36: 293-325.

Tamura, K., D. Peterson, N. Peterson, G. Stecher, M. Nei \& S. Kumar. 2007. MEGA5: Molecular Evolutionary Genetics Analysis using Maximum Likelihood, Evolutionary Distance, and Maximum Parsimony Methods (software version 5.05). Molecular Biology and Evolution (In Press).

Taylor, W. R. \& G. C. van Dyke. 1985. Revised procedures for staining and clearing small fishes and other vertebrates for bone and cartilage study. Cybium, 9: 107-109.

Thompson, J. D., D. G. Higgins \& T. J. Gibson. 1994. CLUSTAL $\mathrm{W}$ : improving the sensitivity of progressive multiple sequence alignment through sequence weighting, position-specific gap penalties and weight matrix choice. Nucleic Acids Research, 22: 4673-4680.

Victor, B. C. 2007. Coryphopterus kuna, a new goby (Perciformes: Gobiidae: Gobiinae) from the western Caribbean, with the identification of the late larval stage and an estimate of the pelagic larval duration. Zootaxa, 1526: 51-61.

Villa-Verde, L. \& W. J. E. M. Costa. 2006. A new glanapterygine catfish of the genus Listrura (Siluriformes: Trichomycteridae) from the southeastern Brazilian coastal plains. Zootaxa, 1142: 43-50.

Villa-Verde, L. 2008. Relações filogenéticas do gênero Listrura de Pinna (Siluriformes: Trichomycterydae: Glanapteryginae). Unpublished MSc. Dissertation, Universidade Federal do Rio de Janeiro, Rio de Janeiro, 128p.

Villa-Verde, L., M. R. Britto \& V. Abilhoa. 2008. Novos exemplares de Listrura boticario de Pinna \& Wosiacki (Siluriformes: Trichomycteridae). Boletim Sociedade Brasileira de Ictiologia, 91: 5-6.

Submitted January 10, 2012

Accepted August 20, 2012

Published September 28, 2012 